\title{
ARTHROPOD ALLERGENS IN URBAN HOMES
}

\author{
Ljerka PRESTER \\ Institute for Medical Research and Occupational Health, Zagreb, Croatia \\ Received in June 2011 \\ CrossChecked in March 2012 \\ Accepted in March 2012
}

\begin{abstract}
Dust mites, cockroaches, and pets (cats, dogs) are common in homes worldwide, and many species are the source of potent allergens which cause allergic diseases. These diseases are influenced by genetic predisposition and environmental exposure. Generally, the levels of house dust mite (Der $p 1$ and Der $\mathrm{f} 1$ ) and cockroach (Bla g 1, Bla g 2) allergens are used as markers of indoor exposure to arthropods.

This article reviews the findings of allergens Der $\mathrm{p} 1$, Der $\mathrm{f}$ 1, and Bla $\mathrm{g} 1$ in randomly selected urban households in Zagreb (Croatia) measured from 2006 to 2010 and compares them with exposure to arthropod allergens in other countries. In short, house dust mite allergen levels in Croatian homes are low, but exposure is common; Der p 1 was found in $73 \%$ and Der $\mathrm{f} 1$ in $83 \%$ of the households. By contrast, exposure to cockroach allergen Bla $g 1$ was both low and uncommon (13\%). Exposure to multiple allergens associated with sensitisation and asthma was not frequent in urban homes in Croatia. However, further studies should include monitoring of both arthropod and pet allergens in high-risk populations in inland and coastal Croatia. They should also investigate a complex dose-response relationship between exposure and sensitisation/asthma development, especially in early childhood.
\end{abstract}

KEY WORDS: Bla g 1, Der f 1, Der p 1, house dust mites, ELISA, indoor allergens

\section{INDOOR ALLERGENS}

Exposure to indoor allergens brings the risk of sensitisation and symptoms of asthma in atopic individuals $(1,2)$. The major biological sources of aeroallergens in homes are arthropods (dust mites and cockroaches), furred pets (primarily cats and dogs), moulds, and pollen (3-5). Table 1 shows common allergens used for indoor exposure assessment. House dust mites Dermatophagoides pteronyssinus and Dermatophagoides farinae are a particularly important source of allergens in homes in the temperate climate (6), Der 1 and Der $\mathrm{f} 1$ in particular (6).The cockroach species Blatella germanica (German cockroach) and Periplaneta americana (American cockroach) are also the source of potent allergens that can trigger allergic reactions. The primary source of dust mite and cockroach allergens has been identified in faecal material, and they present a source of inhaled aeroallergens (7). Furthermore, the increasing number of pets (especially cats and dogs) has raised the level of exposure to the allergens produced by these domestic animals in residential and public places $(8$, 9). While the major cat allergen (Fel d 1) is present mainly on the fur, the primary source of dog allergen, Can $\mathrm{f} 1$, has been identified in the saliva and urine (10). The distribution of all indoor allergens shows regional variations, mainly due to climate factors (1114).

Allergic diseases are common chronic diseases, and their prevalence is increasing in Croatia and in many European countries (6, 15-18). The geneenvironment interactions have a significant role in the sensitisation and exacerbation of childhood asthma, particularly in urban households $(2,3,11,19)$. The outcome of these interactions may be influenced by 
other environmental exposures. Indoor air pollution $\left(\mathrm{NO}_{2}\right.$ and ozone) and passive exposure to tobacco smoke may potentiate allergic sensitisation and exacerbate the existing asthma (20-22). In addition, outdoor pollution such as traffic-related air pollution and pollen allergens has been also associated with asthma attacks in children and adults in several European countries (23).

Table 1 Major house dust allergens

\begin{tabular}{lc}
\hline Source & Allergen \\
\hline Hose dust mite & \\
\hline D. pteronyssinus & Der $\mathrm{p} \mathrm{1,} \mathrm{Der} \mathrm{p} \mathrm{2}$ \\
\hline D. farina & Der f 1, Der f 2 \\
\hline B. tropicalis & Bla t 5 \\
\hline Cockroach & \\
\hline B. germanica & Bla g 1, Bla g 2 \\
\hline$P$. americana & Per a 1 \\
\hline Domestic animals & \\
\hline F. domesticus & Fel d 1 \\
\hline$C$. familiaris & Can d 1 \\
\hline
\end{tabular}

In this article, exposure to common allergens in households in Croatia has been presented and results were compared with our earlier investigations and with reported exposure in other countries.

\section{CHARACTERISTICS OF ARTHROPOD ALLERGENS}

Mite allergens have been well characterised and according to their biological function they are categorised in more than 20 groups of dust mite allergenic proteins (Table 2) (24). The major allergens of $D$. pteronyssinus and D. farinae (Der $\mathrm{p} 1$ and Der f 1) are usually used as markers of exposure to house dust mites in the temperate climate. In the tropical climate, the dominant mite species is B. tropicalis, and its major allergen Blo $t 5$ has been used to assess indoor exposure (25).

Cross-reactivity between Der p 1 and Der f 1 is higher than $80 \%$ (26). Another source of crossreactivity is the group 10 mite allergen tropomyosin, also shared by cockroaches and invertebrates such as squid, crab, and lobster. Exposure to tropomyosin through food may lead to sensitisation to dust mites and vice versa (25). In contrast, allergens from $B$. tropicalis share low-to-moderate cross-reactivity to allergens of other dust mites (25).

Similar to mites, cockroaches produce potent allergens $(6,27)$. While $B$. germanica is common in Europe and North America, P. americana is dominant

Table 2 Categorisation and characteristics of common house dust mite allergens

\begin{tabular}{|c|c|c|}
\hline Group & Allergens & Biological function \\
\hline 1 & Der p 1, Der f 1, Blo t 1 & Cysteine protease \\
\hline 2 & Der $\mathrm{p} 2$, Der f 2, Blo t 2 & Niemann-Pick C2 homologue \\
\hline 3 & Der p 3, Der f 3, Blo t 3 & Trypsin \\
\hline 4 & Der p 4, Blo t 4 & Amylase \\
\hline 5 & Der p 5, Blo t 5 & Unknown \\
\hline 6 & Der p 6, Der f 6 & Chymotrypsin \\
\hline 7 & Der p 7, Der f 7 & Unknown \\
\hline 8 & Der $\mathrm{p} 8$ & Glutathione-S-transferase \\
\hline 9 & Der p 9 & Collagenolytic protease \\
\hline 10 & Der p 10, Der f 10, Blo t 10 & Tropomyosin \\
\hline 11 & Der p 11, Der f 11, Blo t 11 & Paramyosin \\
\hline 12 & Blo t 12 & Unknown \\
\hline 13 & Blo t 13 & Fatty-acid binding protein \\
\hline 14 & Der p 14, Der f 14 & Vitellogenin-apolipophorine like \\
\hline 15 & Der f 15 & Chitinase \\
\hline 16 & Der f 16 & Gelsolin \\
\hline 17 & Der f 17 & Calcium binding protein \\
\hline 18 & Der f 18 & Chitinase-like \\
\hline 19 & Blo t 19 & Antimicrobial peptide \\
\hline 20 & Der $\mathrm{p} 20$ & Arginine kinase \\
\hline 21 & Der p 21, Blo t 21 & Unknown \\
\hline
\end{tabular}

Der p, Dermatophagoides pteronyssinus; Der f, Dermatophagoides farine; Blo t, Blomia tropicalis 
in the tropical countries (6). Cockroach allergens are found in its saliva, faeces, secretions, and dead body. Up to now, 10 cockroach proteins have been identified as allergens in both cockroach species (24). Among them, Bla g 1 and Bla g 2 are the major allergens and they have been commonly used as markers of exposure to cockroach allergens. Bla g 1 and Per a 1 ( $P$. americana) are cross-reactive, while Bla $\mathrm{g} 2$ is speciesspecific (24). Bla g 7 and Per a 7 are tropomyosin, a major allergic component accounting for the crossreactivity between dust mites and cockroaches (24).

\section{AERODINAMIC DIAMETER OF INDOOR ALLERGENS}

Table 3 shows the aerodynamic properties of common indoor allergens. Arthropod allergens have different aerodynamic diameters and distribution than the allergens of pet dander, moulds, and pollen (17, $28)$. Mite allergens are mostly associated with large particles ( $25 \mu \mathrm{m}$ in diameter), which are not respirable. However, a small portion of Der $\mathrm{p} 1$ is associated with particles smaller than $10 \mu \mathrm{m}$, which are respirable and may cause airway inflammation in the lung. Similarly, about $80 \%$ of cockroach allergens Bla g 1 and Bla $g$ 2 are carried on relatively large particles (range $5 \mu \mathrm{m}$ to $40 \mu \mathrm{m}$ in diameter $)(29,30)$.

Cat (Fel d 1) and dog (Can f 1) allergens are associated with both large and small particles (Table 3 ). About $75 \%$ of Fel d 1 is carried on particles $>9$ $\mu \mathrm{m}$ in diameter. However, a considerable amount of Fel $\mathrm{d} 1$ is associated with fine particles of $<5 \mu \mathrm{m}$ in diameter, that are respirable and remain airborne for a long time $(28,10,31)$. Bioaerosol settling is influenced by environmental and physical parameters such as (temperature, relative humidity and air currents) (32). Allergens in settled dust become airborne by human activity (vacuum cleaning) and air currents $(17,31)$.

\section{DETECTION OF ALLERGENS}

\section{Threshold values for indoor allergens}

The dose-response relationship between allergen exposure and sensitisation has well been described in the literature (3-6). Figure 1 shows the generally accepted threshold values (for sensitisation and disease) for common indoor allergens in settled dust. Exposure to mite allergens Der $\mathrm{p} 1$, and Der $\mathrm{f} 1$ of 2 $\mu \mathrm{g} \mathrm{g}^{-1}$ and $10 \mu \mathrm{g} \mathrm{g}^{-1}$ of dust has been regarded as a risk factor for sensitisation and asthma, respectively. However, in sensitised individuals with mild asthma, repeated exposure to low allergen level may lead to chronic asthma (18).

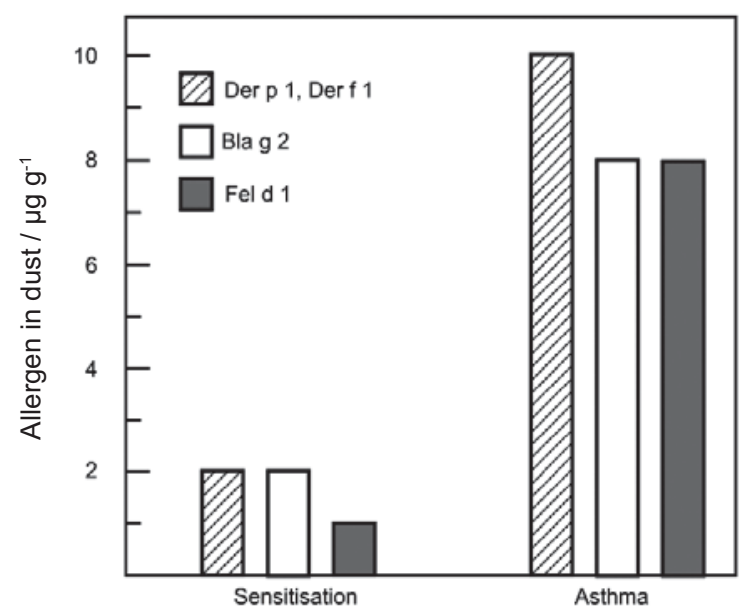

Figure 1 Allergen exposure thresholds for sensitisation and allergic diseases

Table 3 Aerodynamic properties of common indoor allergens

\begin{tabular}{lccc}
\hline Source & Allergen & Particle size & Ref. \\
\hline Mite & Der p 1, Der f 1 & Large particles, $25 \mu \mathrm{m}$ & 7,29 \\
\hline Cockroach & Bla g 1, Bla g 2 & & $10,28,62$ \\
Cat & Fel d 1 & $\begin{array}{c}\text { Large particles }>10 \mu \mathrm{m}(75 \%) \\
\text { Small particles }<5 \mu \mathrm{m}(25 \%)\end{array}$ & 77 \\
\hline Dog & Can f 1 & Large particles, 10 to $40 \mu \mathrm{m}$ & 78 \\
\hline $\begin{array}{l}\text { Moulds } \text { alternata } \\
\text { Aumigatus }\end{array}$ & Alt a 1 & Small particles $<5 \mu \mathrm{m}$ & 78 . \\
\hline Grass pollen & Asp f 1 & Small particle, 0.5 to $2.5 \mu \mathrm{m}$ & Larger particles $>7.2 \mu \mathrm{m}$ \\
\hline
\end{tabular}




\section{Allergen sampling}

Allergens of mites and cockroaches have usually been quantified in reservoir dust (floors, carpets, or beds) due to their extremely low air concentration. In contrast, cat and dog allergens are measured both in air-borne and dust-borne samples (33-35).

\section{ELISA measurement}

Currently, capture enzyme-linked immunosorbent assay (ELISA) is the gold standard for indoor allergen analysis $(3,4,36,37)$. In our previous studies, we used the following monoclonal antibodies $(\mathrm{mAb})$ for capture: anti Der p 1 (clone 5H8), anti Der $\mathrm{f} 1$ (clone 6H8), and anti-Bla g1 (clone 10A6). Der p 1 and Der $\mathrm{f} 1$ were detected using biotinilated $\mathrm{mAb} 4 \mathrm{C}$, while Bla $\mathrm{g} 1$ was detected using the polyclonal rabbit serum anti- $B$. germanica. Several years ago, a fluorescent multiplex array was developed for simultaneous

Table 4 Distribution of mite and cockroach allergens in household dust (Zagreb, Croatia)

\begin{tabular}{|c|c|c|c|}
\hline Allergen & $\begin{array}{l}\text { Number of } \\
\text { samples / \% }\end{array}$ & Median & Ref \\
\hline Der p 1 & & $0.32 \mu \mathrm{g} \mathrm{g}^{-1}$ & 36 \\
\hline Detectable & 73 & & \\
\hline$>2 \mu \mathrm{g} \mathrm{g}^{-1}$ & 13.3 & & \\
\hline$>10 \mu \mathrm{g} \mathrm{g}^{-1}$ & 3.3 & & \\
\hline Der f 1 & & $0.35 \mu \mathrm{g} \mathrm{g}^{-1}$ & 36 \\
\hline Detectable & 83 & & \\
\hline$>2 \mu \mathrm{g} \mathrm{g}^{-1}$ & 6.6 & & \\
\hline$>10 \mu \mathrm{g} \mathrm{g}^{-1}$ & 10 & & \\
\hline Bla g 1 & & $0.74 \mathrm{U} \mathrm{g}^{-1}$ & 37 \\
\hline Detectable & 13.3 & & \\
\hline$>2 \mathrm{U} \mathrm{g}^{-1}$ & 3.3 & & \\
\hline$>8 \mathrm{U} \mathrm{g}^{-1}$ & 0 & & \\
\hline
\end{tabular}

measurement of six indoor allergens from a single sample (38). This array is especially suitable for large epidemiological studies involving hundreds of samples analysed for multiple allergens.

\section{EXPOSURE TO ARTHROPOD ALLERGENS}

Mites

Most homes in the temperate climate are inhabited by multiple mite species (39). D. pteronyssinus and $D$. farinae dominate the inland and coastal Croatia. However, the coastal areas also report Blomia spp, Lepidoglyphus spp., and Glycyphaus spp (about $10 \%$ ), mainly due to higher air temperature (14). Table 4 shows the median Der $\mathrm{p} 1$ and Der $\mathrm{f} 1$ in living room dust samples of the general population in inland Croatia (Zagreb). Mite allergens are common in Zagreb; however, their levels are low (36). In the coastal Croatia, Der p1 level is significantly higher than inland, which suggests that exposure to mite allergens varies with climate (14). Similar interregional differences in mite populations and allergen levels were observed in Spain (40). The population dynamic of dust mites is influenced by temperature, humidity, and housing characteristics (heating, ventilation) $(14,41,42)$.

Table 5 shows exposure profiles to mite allergens in floor dust (uncarpeted) in different geographic locations worldwide. There are large qualitative and quantitative differences in mite allergen levels between countries. Even though exposure to mite allergens is extremely low in Iceland, sensitisation is higher than expected (9\%) (43). The highest levels of Der p 1 were reported in Australia and New Zealand (Table

Table 5 Mite allergens ( $\left.\mu g^{-1}\right)$ in floor dust samples (median or geometric mean)

\begin{tabular}{lcccc}
\hline Der p 1 & Der f 1 & Population, $\mathbf{n}$ & City, Country & Ref \\
\hline$<$ LOD & $<$ LOD & General, 197 & Reykjavik, Iceland & 43 \\
\hline 0.035 & 0.27 & General, 578 & Hamburg, Germany & 53 \\
\hline 0.15 & 0.83 & General, 44 & Pavia, Italy & 46 \\
\hline 0.26 & 0.75 & High-risk, 750 & Northeastern United States & 79 \\
\hline 0.77 & High-risk, 369 & Barcelona, Spain & 40 \\
\hline 0.94 & High-risk, 76 & The Netherlands & 80 \\
\hline 1.36 & High-risk, 624 & Ashford, United Kingdom & 40 \\
\hline 1.59 & General, 40 & Hong Kong, China & 51 \\
\hline 9.04 & High-risk, 481 & Menorca, Spain & 40 \\
\hline 9.37 & High-risk, 590 & Sydney, Australia & 44 \\
\hline 17.2 & & High-risk, 447 & Melbourne, Australia & 45 \\
\hline
\end{tabular}


5). In parts of the coastal Australia, concentrations of Der p1 exceeded the higher threshold of $10 \mu \mathrm{g} \mathrm{g}^{-1}$ in about $80 \%$ of homes $(44,45)$. In Croatia by contrast, Der $\mathrm{p} 1$ and Der $\mathrm{f} 1$ exceeded this threshold in less than $10 \%$ of homes (36). Similarly, about $10 \%$ to $15 \%$ of homes in the United Kingdom and Italy exceeded this threshold $(46,47)$. The distribution of dust mite species differs between tropical and temperate areas. B. tropicalis dominates in tropical and sub-tropical climates. High level of Blo t 5, a major allergen of $B$. tropicalis, was reported in Singapore house dust (48).

In addition, several studies have shown that mite allergen levels were higher in carpeted bedrooms than in uncarpeted rooms in the same dwelling (49). Antens et al. (50) reported six to fourteen times lower dust mite allergen concentrations in uncarpeted than carpeted floors. In addition to floor dust, mite allergens have also been determined in mattress dust $(12,51)$ and beds (52).

\section{Cockroaches}

German cockroach (B. germanica) is the dominant species in Croatia. Our previous study showed low exposure to Bla g 1, a major allergen of the German cockroach, in the general population of Zagreb (37). In most samples Bla $\mathrm{g} 1$ was below the limit of detection, and only $3.3 \%$ of the samples had Bla $\mathrm{g} 1$ above the sensitisation threshold of $2 \mathrm{Ug} \mathrm{g}^{-1}$. Similarly low exposure to cockroach allergens has been reported in Germany (53) and in Canada (20). In contrast, Bla g 1 or Bla 2 levels were considerably higher in residential dust samples collected in the homes of asthmatic children of low socioeconomic status in the US $(6,54)$. Bla $g 1$ was the predominant indoor allergen and a major risk for children with asthma in urban homes in the US (55-59). The frequency of allergy to cockroach in the asthmatic population of the US is much higher (about $50 \%$ ) than in Germany (4.2\%) (60) and Croatia (9.6\%) (61). Therefore, rare allergies to cockroach in these European countries correspond to low Bla g 1 and Bla $\mathrm{g} 2$ levels in house dust samples.

\section{EXPOSURE TO CAT AND DOG ALLERGENS}

Cat allergens can be found in cat-free homes, public places, and workplaces $\left(>1 \mu \mathrm{g} \mathrm{g}^{-1}\right)$ where they are brought by their owners $(8,34,62)$. Generally, the levels of airborne cat allergens in cat-free homes can suffice to cause sensitisation and symptoms in atopic individuals (62). As expected, the levels of cat and dog allergens (Fel d1 and Can f 1, respectively) in houses with cats and dogs is much higher $\left(>100 \mu \mathrm{g} \mathrm{g}^{-1}\right)$ than in cat- or dog-free environments $(34,62)$. Parvaneh et al. (34) found a moderately strong correlation between airborne and dustborne Fel d 1 levels in homes with cats. Generally, exposure to cat and dog allergens in homes and public places is much higher than exposure to mite and cockroach allergens. For example, in homes with cats, the level of Fel d 1 was found to be about 100 times higher than the level of Der $p 1(34,62)$.

\section{ENVIRONMENTAL CONTROL}

Environmental control is a part of a wide strategy to treat allergic patients and to reduce the severity of asthma (28). Allergen avoidance makes part of the primary prevention for infants at high risk of developing allergic diseases and secondary prevention for patients with established sensitisation and diseases (28). HEPA air cleaners have a beneficial role in patients sensitised to pet allergens, as they efficiently capture the relatively small particles carrying pet allergens (63). However, air cleaners are not efficient in reducing exposure to house dust mite allergens (10). Other measures are used instead, including encasing mattresses and pillows with impermeable covers, removing the carpets, minimising upholstered furniture, vacuuming with a HEPA filter, and washing all bedding in the hot cycle $\left(60^{\circ} \mathrm{C}\right)(28)$.

In combination with these avoidance measures, keeping the humidity below $50 \%$ and increasing bedroom ventilation can also help to reduce the levels of indoor allergens (12). However, cockroach allergens may be more difficult to remove from homes even if the cockroach population has been substantially downsized (27). Measures for reducing indoor reservoir allergens and for asthma prevention have been described in detail elsewhere $(4,12,19,28,49$, 63-65).

\section{CLINICAL ASPECTS}

\section{Indoor allergens and asthma}

A dose-response relationship between the level of exposure to dust mite allergens and sensitisation has 
been well documented (66) (Figure 1). Particularly high levels of dust mite allergens $\left(>10 \mu \mathrm{g} \mathrm{g}^{-1}\right)$ in early childhood have been associated with frequent and severe asthma development in atopic children (18, 66). Exposure to cockroach $(19,57,59)$ and cat $(45)$ allergens has also been associated with sensitisation in genetically predisposed children. All this suggests that infancy may be a critical time for exposure to common indoor allergens and later development of asthma. However, although the relationship between allergen exposure and asthma is widely accepted, several recent studies challenge this dose-response concept (67-70). Tovey et al. (69) found a nonlinear relationship between high-level exposure $(>23.4 \mu \mathrm{g}$ $\left.\mathrm{g}^{-1}\right)$ to Der p 1 and the prevalence of asthma and eczema. Exposure to high levels of this allergen is common in the coastal Australia. Similarly, Torrent et al. $(40,70)$ found a nonlinear relationship between exposure to Fel $\mathrm{d} 1$ and sensitisation in small children. Some authors suggest that early high-level exposure to Fel $\mathrm{d} 1\left(>20 \mu \mathrm{g} \mathrm{g}^{-1}\right)$ is associated with higher production of specific IgG4 antibody and decreased cat-specific IgE response, which could result in better protection against sensitisation $(62,71,72)$. This induction of tolerance to Fel $\mathrm{d} 1$ could actually reduce the risk of allergy development $(11,18,71)$

In addition to mite, cockroach, and pet allergens, mould and pollen allergens, viral infections, and especially tobacco smoke may contribute to the development of sensitisation and respiratory diseases $(2,10,73)$.

\section{Hygiene hypothesis}

This so-called hygiene hypothesis suggests that increased exposure to bacterial endotoxins in early childhood protects against allergy and asthma by inhibiting Th2-type immune responses $(1,18)$. Although early endotoxin exposure may be protective against atopy, it can present a risk for wheeze in sensitive children (66). Gehring et al. (74), showed an inverse relationship between indoor endotoxin levels and the occurrence of asthma, but not for rhinitis (74). Domestic animals are usually a source of endotoxin, and keeping a cat or dog in the first year of life may reduce a child's risk of allergic disease (72). Similarly, other studies showed a lower prevalence of allergic diseases among rural adolescents raised on a farm with animals than among children growing up in urban environments without animals $(75,76)$. Platts-Mills et al. (71) suggested that endotoxin exposure may prevent allergen-specific Th2 cytokine production and direct it toward a Th1-type response.

\section{CONCLUSION}

The incidence of allergic diseases has been increasing in many developed counties over the last few decades. Despite many advances in understanding the factors associated with the development of asthma, the natural history of asthma is not absolutely clear. A better characterisation of indoor allergens (molecular structures of allergens, biological functions) and investigations into the genetic susceptibility of atopics to these allergens could help to understand the complex gene-environment interactions and the basic mechanisms of allergy development.

\section{Acknowledgement}

This research was supported by the Croatian Ministry of Science, Education and Sports (grant no. 022-0222411-2410).

\section{REFERENCES}

1. Wang DY. Risk factors of allergic rhinitis: genetic or environmental? Ther Clin Risk Manag 2005;1:115-23.

2. Gold DR. Environmental tobacco smoke, indoor allergens, and childhood asthma. Environ Health Perspect 2000;108(Suppl 4):643-51.

3. Salo PM, Arbes SJ, Crockett PW, Thorne PS, Cohn RD, Zeldin DC. Exposure to multiple indoor allergens in US homes and its relationship to asthma. J Allergy Clin Immunol 2008;121:678-84.

4. Platts-Mills TA, Vervloet D, Thomas WR, Aalberse RC, Chapman MD. Indoor allergens and asthma: report of the Third International Workshop. J Allergy Clin Immunol 1997;100:S2-S24.

5. Leaderer BP, Belanger K, Triche E, Holford T, Gold DR, Kim Y, Jankun T, Ren P, McSharry J, Platts-Mills TA, Chapman MD, Bracken MB. Dust mite, cockroach, cat, and dog allergen concentrations in homes of asthmatic children in the northeastern United States: impact of socioeconomic factors and population density. Environ Health Perspect 2002;110(Suppl 4):419-25.

6. Arlian LG. Arthropod allergens and human health. Annu Rev Entomol 2002;47:395-433.

7. De Lucca S, Sporik R, O'Meara TJ, Tovey ER. Mite allergen (Der p 1) is not only carried on mite feces. J Allergy Clin Immunol 1999;103:174-5.

8. Liccardi G, D'Amato G, Russo M, Canonica GW, D'Amato L, De Martino M, Passalacqua G. Focus on cat allergen (Fel d 1): immunological and aerodynamic characteristics, 
modality of airway sensitization and avoidance strategies Int Arch Allergy Immunol 2003;131:1-12.

9. Segundo GRS, Sopelete MC, Terra SA, Pereira FL, Justino CM, de Oliveira Silva DA, Taketomi EA. Diversity of allergen exposure: implications for the efficacy of environmental control. Braz J Otorhinolaryngol 2009;75:3116.

10. Custovic A, Simpson A, Pahdi H, Green RM, Chapman MD, Woodcock A. Distribution, aerodynamic characteristics, and removal of the major cat allergen Fel d 1 in British homes. Thorax 1998;53:33-8.

11. Gaffin JM, Phipatanakul W. The role of indoor allergens in the development of asthma. Curr Opinion Allergy Clin Immunol 2009;9:128-35.

12. Zock JP, Heinrich J, Jarvis D, Verlato G, Norbäck D, Plana E, Sunyer J, Chinn S, Olivieri M, Soon A, Villani S, Ponzio M, Dahlman-Hoglund A, Svanes C, Luczynska C. Distribution and determinants of house dust mite allergens in Europe: The European Community Respiratory Health Survey II. J Allergy Clin Immunol 2006;118:682-90.

13. Arlian LG, Bernstein D, Bernstein IL, Freidman S, Grant A, Lieberman P, Lopez M, Metzger J, Platts-Mill T, Schatz M, Spector S, Wasserman SI, Zeiger RS. Prevalence of dust mites in homes of people with asthma living in eight different geographic areas of the United States. JAllergy Clin Immunol 1992;90:292-300.

14. Macan J, Kanceljak B, Plavec D, Milković-Kraus S. Differences in mite fauna between the continental and mediterian climates of Croatia: Microscopy and Dustscreen ${ }^{\mathrm{TM}}$ test findings. Allergy 2003;58:780-3.

15. Banac S, Lah Tomulić K, Ahel V, Rožmanić V, Šimundić N, Zubović S, Milardović A, Topić J. Prevalence of asthma and allergic diseases in Croatian children is increasing: Survey study. Croat Med J 2004;45:721-6.

16. Gelfand EW. Pediatric asthma : a different disease. Proc Am Thorac Soc 2009;6:278-82.

17. Raja S, Xu Y, Ferro AR, Jaques PA, Hopke PK. Resuspension of indoor aeroallergens and relationship to lung inflammation in asthmatic children. Environ Int 2010;36:8-14.

18. Arshad SH. Does exposure to indoor allergens contribute to the development of asthma and allergy? Curr Allergy Asthma Rep 2010;10:49-55.

19. Crain EF, Walter M, O'Connor GT, Mitchell H, Gruchalla RS, Kattan M, Malindzak GS, Enright P, Evans R, Morgan W, Stout JW. Home and allergic characteristics of children with asthma in seven U.S. urban communities and design of an environmental intervention: the inner-city asthma study. Environ Health Perspect 2002;110:939-45.

20. Loo CK, Foty RG, Wheeler AJ, Miller JD, Evans G, Stieb DM, Dell SD. Do questions reflecting indoor air pollutant exposure from a questionnaire predict direct measure of exposure in owner-occupied houses? Int J Environ Res Public Health 2010;7:3270-97.

21. Saglani S, McKenzie SA. Environmental factors relevant to difficult asthma. Paediatr Respir Rev 2002;3:248-54.

22. Raherison C, Pénard-Morand C, Moreau D, Caillaud D, Charpin D, Kopferschmitt C, Lavaud F, Taytard A, Maesano A. Smoking exposure and allergic sensitization in children according to maternal allergies. Ann Allergy Asthma Immunol 2008;100:351-7.

23. Künzli N, Kaiser R, Medina S, Studnicka M, Chanel O, Filliger P, Herry M, Horak Jr F, Puybonnieux-Texier V,
Quénel P, Schneider J, Seethaler R, Vergnaud JC, Sommer H. Public-health impact of outdoor and traffic-related air pollution: a European assessment. Lancet 2000;356:795801.

24. Yong TS, Jeong KY. Household anthropod allergens in Korea. Korean J Parasitol 2009;47(Suppl):S143-53.

25. Chua KY, Cheong N, Kuo IC, Lee BW, Yi FC, Huang CH, Liew LN. The Blomia tropicalis allergens. Protein Pept Lett 2007; 14:325-33.

26. Cruz LM, López-Malpica F, Diaz AN. Analysis of crossreactivity between group 1 allergens from mites. P R Health Sci J 2008;27:163-70

27. Arruda LK, Vailes LD, Ferriani VPL, Santos ABR, Pomés A, Chapman MD. Cockroach allergens and asthma. J Allergy Clin Imminol 2001;107:419-28.

28. Woodcock A, Custovic A. Allergen avoidance: does it work? Br Med Bull 2000;56:1071-86.

29. De Blay F, Sanchez J, Hedelin G, Perez-Infante A, Vérot A, Chapman M, Pauli G. Dust and airborne exposure to allergens derived from cockroach (Blattella germanica) in low-cost public housing in Strasbourg (France). J Allergy Clin Immunol 1997;99:107-12.

30. De Lucca SD, Taylor DJM, O'Meara TJ, Jones AS, Tovey ER. Measurement and characterization of cockroach allergens detected during normal domestic activity. J Allergy Clin Immunol 1999;104:672-80.

31. Montoya LD, Hildemann LM. Size distributions and height variations of airborne particulate matter and cat allergen indoors immediately following dust-disturbing activities. J Aerosol Sci 2005;36:735-49.

32. Paufler P, Gebel T, Dunkelberg H. Quantification of house dust mite allergens in ambient air. Rev Environ Health 2001;16:65-80.

33. Luczynska CM. Sampling and assay of indoor allergens. J Aerosol Sci 1997;28:393-9.

34. Custovic A, Simpson B, Simpson A, Hallam C, Craven M, Woodcock A. Relationship between mite, cat, and dog allergens in reservoir dust and ambient air. Allergy 1999;54:612-6.

35. Parvaneh S, Ahlf E, Elfman LHM, van Hage-Hamsten M, Elfman L, Nybom R. A new method for collecting airborne allergens. Allergy 2000;55:1148-54.

36. Prester Lj, Brčić Karačonji I, Macan J. Determination of mite allergens in house dust using the enzyme immunoassay. Arhiv Hig Rada Toksikol 2007;58:413-9.

37. Prester Lj, Macan J. Bla g 1 allergen levels in Zagreb area household dust. Arh Hig Rada Toksikol 2011;62:33-9.

38. Earle CD, King EM, Tsay A, Pittman K, Saric B, Vailes L, Godbout R, Oliver KG, Chapman MC. High-throughput fluorescent multiplex array for indoor allergen exposure assessment. J Allergy Clin Immunol 2007;119:428-33.

39. Warner A, Boström S, Munir AK, Möller C, Schou C, Kjellman NI. Environmental assessment of Dermatophagoides mite-allergen levels in Sweden should include Der $\mathrm{m} 1$. Allergy 1998;53:698-701.

40. Torrent M, Sunyer J, Garcia R, Harris J, Iturriaga MV, Puig C, Vall O, Anto JM, Newman Taylor AJ, Cullinan P. Early-life allergen exposure and atopy, asthma, and wheeze up to 6 years of age. Am J Respir Crit Care Med 2007;176:446-53.

41. Hirsch T, Hering M, Bürkner K, Hirsch D, Leupold W, Kerkmann ML, Kuhlisch E, Jatzwauk L. House-dust-mite allergen concentrations (Der f 1) and mold spores in 
apartment bedrooms before and after installation of insulated windows and central heating system. Allergy 2000;55:7983.

42. de Andrade D, Birnbaum J, Lanteaume A, Izard JL, Corget P, Artillan MF, Toumi M, Vervloet D, Charpin D. Housing and house-dust mites. Allergy 1995;50:142-6.

43. Hallas TE, Gislason D, Björnsdottir US, Jörundsdottir KB, Janson C, Luczynska CM, Gislason T. Sensitization to house dust mites in Reykjavik, Iceland, in the absence of domestic exposure to mites. Allergy 2004;59:515-9.

44. Mihrshahi S, Marks G, Vanlaar C, Tovey E, Peat J. Predictors of high house dust mite allergen concentrations in residential homes in Sydney. Allergy 2002;57:137-42.

45. Dharmage S, Bailey M, Raven J, Mitakakis T, Cheng A, Guest D, Rolland J, Forbes A, Thien F, Abramson M, Walters EH. Current indoor allergen levels of fungi and cats, but not house dust mites, influence allergy and asthma in adults with high dust mite exposure. Am J Respir Crit Care Med 2001;164:65-71.

46. Moscato G, Perfetti L, Galdi E, Pozzi V, Minoia C. Levels of house-dust-mite allergen in homes of nonallergic people in Pavia, Italia. Allergy 2000;55:873-8.

47. Simpson A, Simpson B, Custovic A, Cain G, Craven M, Woodcock A. Household characteristics and mite allergen levels in Manchester, UK. Clin Exp Allergy 2002;32:14139.

48. Yi FC, Lee BW, Cheong N, Chua KY. Quantification of Blo t 5 in mite and dust extracts by two-site ELISA. Allergy 2005;60:108-12.

49. Hill DJ, Thompson PJ, Stewart GA, Carlin JB, Nolan TM, Kemp AS, Hosking CS. The Melbourne house dust mite study: eliminating house dust mites in the domestic environment. J Allergy Clin Immunol 1997;99:323-9.

50. Antens CJM, Oldenwening M, Wolse A, Gehring U, Smit HA, Aalberse RC, Kerkhof M, Gerritsen J, de Jongste JC, Brunekreef B. Repeated measurements of mite and pet allergen levels in house dust over a time period of 8 years. Clin Exp Allergy 2006;36:1525-31.

51. Leung R, Lam CWK, Chan A, Lee M, Chan HIS, Pang SW, Lai CKW. Indoor environment of residential homes in Hong Kong-relevance to asthma and allergic diseases. Clin Exp Allergy 1998;28:585-90.

52. Arbes SJ, Cohn RD, Yin M, Muilenberg ML, Burge HA, Friedman W, Zeldin DC. House dust mite allergen in US beds: results from the Fist National Survey of Lead and Allergens in Housing. J Allergy Clin Immunol 2003;111:40814.

53. Fahlbusch B, Heinrich J, Gro $\beta$ I, Jäger L, Richter K, Wichmann HE. Allergens in house-dust samples in Germany: results of an East-West German comparison. Allergy 1999;54:1215-22.

54. Kitch BT, Chew G, Burge HA, Muilenberg ML, Weiss ST, Platts-Mills TAE, O'Connor G, Gold DR. Socioeconomic predictors of high allergen levels in homes in the greater Boston area. Environ Health Perspect 2000;108(Suppl 4):301-7

55. Cohn RD, Arbes SJ Jr, Jaramillo R, Reid LH, Zeldin DC. National prevalence and exposure risk for cockroach allergen in U.S. Households. Environ Health Perspect 2006;114:5226.

56. Eggleston PA, Rosenstreich D, Lynn H, Gergen P, Baker D, Kattan M, Mortimer KM, Mitchell H, Ownby D, Slavin R,
Malveaux F. Relationship of indoor allergen exposure to skin test sensitivity in inner-city children with asthma. J Allergy Clin Immunol 1998;102:563-70.

57. Peters JL, Levy JI, Rogers CA, Burge HA, Spengler JD. Determinants of allergen concentrations in apartments of asthmatic children living in public housing. J Urban Health 2007;84:185-97.

58. Huss K, Adkinson FN, Eggleston PA, Dawson C, Van Natta ML, Hamilton RG. House dust mite and cockroach exposure are strong risk factors for positive allergy skin test responses in the Childhood Asthma Management Program. J Allergy Clin Immunol 2001;107:48-54.

59. Gruchalla RS, Pongracic J, Plaut M, Evans R, Visness CM, Walter M, Crain EF, Kattan M, Morgan WJ, Steinbach S, Stout J, Malindzak G, Smartt E, Mitchell H. Inner city asthma study: Relationships among sensitivity, allergen exposure, and asthma morbidity. J Allergy Clin Immunol 2005, 115:47885.

60. Hirsch T, Stappenbeck C, Neumeister V, Weiland SK, von Mutius E, Keil U, Leupold W. Exposure and allergic sensitization to cockroach allergen in East Germany. Clin Exp Allergy 2000;30:529-37.

61. Macan J, Plavec D, Kanceljak B, Milković-Kraus S. Exposure levels and skin reactivity to German cockroach (Blatella germanica) in Croatia. CMJ 2003;44(6):756-60.

62. Custis NJ, Woodfolk JA, Vaughan JW, Platts-Mills TAE. Quantitative measurement of airborne allergens from dust mites, dogs, and cats using an ion-charging device. Clin Exp Allergy 2003;33:986-91.

63. van der Heide S, van Aalderen WMC, Kauffman HF, Dubois AEJ, de Monchy JGR. Clinical effects of air cleaners in homes of asthmatic children sensitized to pet allergens. J Allergy Clin Immunol 1999;104:447-51.

64. Gergen PJ, Mortimer KM, Eggleston PA, Rosenstreich D, Mitchell H, Ownby D, Kattan M, Baker D, Wright EC, Slavin R, Malveaux F. Results of the National Cooperative InnerCity Asthma study (NCICAS) environmental intervention to reduce cockroach allergen exposure in inner-city homes. J Allergy Clin Immunol 1999;103:501-6.

65. Halken S, Høst A, Niklassen U, Hansen LG, Nielsen F, Pedersen S, Østerballe O, Veggerby C, Poulsen LK. Effect of mattress and pillow encasings on children with asthma and house dust mite allergy. J Allergy Clin Immunol 2003;111:169-76.

66. Celedón JC, Milton DK, Ramsey CD, Litonjua AA, Ryan L, Platts-Mills TAE, Gold DR. Exposure to dust mite allergen and endotoxin in early life and asthma and atopy in childhood. J Allergy Clin Immunol 2007;120:144-9.

67. von Hertzen L, Haahtela T. Con: House dust mites in atopic diseases. Am J Respir Crit Care Med 2009;180:113-9.

68. Cole Johnson C, Ownby DR, Havstad SL, Peterson EL. Family history, dust mite exposure in early childhood, and risk for pediatric atopy and asthma. J Allergy Clin Immunol 2004; $114: 105-10$.

69. Tovey ER, Almqvist C, Li Q, Crisafulli D, Marks GB. Nonlinear relationship of mite allergen exposure to mite sensitization and asthma in a birth cohort. J Allergy Clin Immunol 2008;122:114-8.

70. Torrent M, Sunyer J, Muňoz L, Cullinan P, Iturriaga MV, Figueroa C, Vall O, Taylor AN, Anto JM. Early-life domestic aeroallergen exposure and IgE sensitization at age 4 years. J Allergy Clin Immunol 2006;118:742-8. 
71. Platts-Mills T, Vaughan J, Squillace S, Woodfolk J, Sporik R. Sensitization, asthma, and a modified Th2 response in children exposed to cat allergen: a population-based crosssectional study. Lancet 2001;357:752-6.

72. Ownby DR, Cole Johnson C, Peterson EL. Exposure to dogs and cats in the first year of life and risk of allergic sensitization at 6 to 7 years of age. JAMA 2002;288:963-72.

73. Kumar R. Prenatal factors and the development of asthma. Curr Opin Pediatr 2008:20:682-7.

74. Gehring U, Strikwold M, Schram-Bijkerk D, Weinmayr G, Genuneit J, Nagel G, Wickens K, Siebers R, Crane J, Doekes G, Di Domenicantonio R, Nilsson L, Priftanji A, Sandin A, El-Sharif N, Strachan D, van Hage M, von Mutius E, Brunekreef B. Asthma and allergic symptoms in relation to house dust endotoxin: Phase Two of the International Study on Asthma and Allergies in Childhood (ISAAC II). Clin Exp Allergy 2008;38:1911-20.

75. Remes ST, Koskela HO, Iivanainen K, Pekkanen J. Allergenspecific sensitization in asthma and allergic diseases in children: the study on farmers' and non-farmers' children. Clin Exp Allergy 2005;35:160-6.

76. Riedler J, Eder W, Oberfeld G, Schreuer M. Austrian children living on a farm have less hay fever, asthma and allergic sensitization. Clin Exp Allergy 2000;30:194-200.
77. Stetzenbach LD, Buttner MP, Cruz P. Detection and enumeration of airborne biocontaminants. Curr Opin Biotechnol 2004;15:170-4.

78. Schäppi GF, Taylor PE, Pain MCF, Cameron PA, Dent AW, Staff IA, Suphioglu C. Concentrations of major grass group 5 allergens in pollen grains and atmospheric particles: implications for hay fever and allergic asthma suffers sensitized to grass pollen allergens. Clin Exp Allergy 1999;29:633-41.

79. van Strien RT, Gehring U, Belanger K, Triche E, Gent J, Bracken MB, Leaderer BP. The influence of air conditioning, humidity, temperature and other household characteristics on mite allergen concentrations in the northeastern United States. Allergy 2004:59:645-52.

80. Cloosterman SGM, Schermer TRJ, Bijl-Hofland ID, van der Heide S, Brunekreef B, van den Elshout FJJ, van Herwaarden CLA, van Schayck CP. Effects of house dust mite avoidance measures on Der $\mathrm{p} 1$ concentrations and clinical condition of mild adult house dust mite-allergic asthmatic patients, using no inhaled steroids. Clin Exp Allergy 1999;29:1336-46. 


\section{Sažetak}

\section{ALERGENI ARTROPODA U GRADSKIM STANOVIMA}

Prašinske grinje, žohari i kućni ljubimci (mačka, pas) česti su u stanovima širom svijeta, a mnoge vrste su izvor jakih alergena koji uzrokuju alergijske bolesti. Uzroci alergijskih bolesti su genetska predispozicija i utjecaj okoliša. Alergeni prašinskih grinja (Der p 1 i Der f 1) i žohara (Bla g 1 i Bla g 2) pokazatelji su izloženosti artropodima u kućanstvu. U ovom je radu prikazana izloženost alergenima Der p 1, Der f 1 i Bla g 1 u neselektivnim, urbanim kućanstvima u Zagrebu (Hrvatska) tijekom 2006.-2010. godine, a rezultati su uspoređeni s razinom alergena artropoda u drugim zemljama. Razina alergena grinja Der p 1 i Der f 1 u kućnoj prašini u općoj populaciji u Hrvatskoj je niska, ali su ti alergeni određeni u 73 do 83 \% kućanstva. Nasuprot tome, izloženost alergenu žohara je rijetka (13\%), a razina izloženosti je također niska. Opća populacija u Hrvatskoj nije izložena višestrukim i rizičnim razinama alergena vezanim za razvoj senzibilizacije i astme. Buduća bi ispitivanja trebala uključiti mjerenje alergena artropoda i kućnih ljubimaca u kućanstvima visokorizičnih osoba na nastanak alergijskih bolesti u kontinentalnom i obalnom području Hrvatske. Nova istraživanja povezanosti razine alergena unutarnjih prostora i pojave senzibilizacije i astme naročito u ranom djetinjstvu (učinak ovisan o dozi), trebala bi rezultirati boljim tumačenjem te složene interakcije.

KLJUČNE RIJEČI: alergeni unutarnjih prostora, grinje kućne prašine, Der $p 1$, Der $f 1$, Bla $g$, ELISA

\section{CORRESPONDING AUTHOR:}

\section{Ljerka Prester}

Institute for Medical Research and Occupational Health

Ksaverska cesta 2, HR-10000 Zagreb, Croatia

E-mail:prester@imi.hr 